\title{
Correction: Widespread evidence for horizontal transfer of transposable elements across Drosophila genomes
}

\author{
Carolina Bartolomé, Xabier Bello and Xulio Maside*
}

\section{Correction}

It has been brought to our attention that there is an error in the estimated time of occurrence of horizontal transfers in the Drosophila genome in our article [1]. The twelfth paragraph of the Results and discussion section should read:

The distributions of Ks values among the littlediverged TEs display a peak within the range 0.03-0.05 (Figure 3). If we assume a mutational clock of 0.011 substitutions per nucleotide per million years [46], this suggests that most HT has occurred over a broad period of time centered between 1.4 and 2.3 MYA, well after the split of the D. melanogaster and D. simulans lineages $5.4+/-1.1$ MYA or the time of their most recent common ancestor with $\mathrm{D}$. yakuba, $12.8+/-2.7$ MYA [46].

Received: 15 November 2011 Accepted: 23 November 2011

Published: 15 January 2012

\section{Reference}

1. Bartolome C, Bello X, Maside X: Widespread evidence for horizontal

transfer of transposable elements across Drosophila genomes. Genome Biology 2009, 10:R22

doi:10.1186/gb-2011-12-11-411

Cite this article as: Bartolomé et al: Correction: Widespread evidence for horizontal transfer of transposable elements across Drosophila genomes. Genome Biology 2011 12:411.
* Correspondence: xulio.maside@usc.es

Dpto de Anatomía Patolóxica e Ciencias Forenses, Grupo de Medicina Xenómica-CIBERER, Universidade de Santiago de Compostela, Rúa de San Francisco s/n, Santiago de Compostela, 15782, Spain
Submit your next manuscript to BioMed Central and take full advantage of:

- Convenient online submission

- Thorough peer review

- No space constraints or color figure charges

- Immediate publication on acceptance

- Inclusion in PubMed, CAS, Scopus and Google Scholar

- Research which is freely available for redistribution
Ciomed Central 